\title{
Evaluation of immunoassays for the detection and typing of PCR amplified human papillomavirus DNA
}

S Venturoli, M Zerbini, M La Placa Jr, A D’Antuono, M Negosanti, G Gentilomi, G Gallinella, E Manaresi, M Musiani

\begin{abstract}
Aims-To evaluate different hybridisation techniques to detect and type human papillomavirus (HPV) DNAs amplified by consensus primer polymerase chain reaction (PCR) in biopsy and cytological specimens.

Methods-A hybrid capture-immunoassay in microtitre wells was performed to detect HPV sequences amplified by PCR and typed by specific oligoprobes. Consensus primers were used to amplify a sequence within the $L 1$ open reading frame, and direct digoxigenin labelling of amplified products was performed during the amplification reaction. The amplified product was separately hybridised with six biotinylated type specific probes (HPV6, 11, 16, 18,31 , and 33); hybrids were then captured into streptavidin coated microtitre wells and detected by a spectrophotometer as an ELISA using antidigoxigenin Fab fragment labelled with peroxidase and a colorimetric substrate. The results were compared with the dot-blot immunoassay used to detect and type PCR amplified HPV DNA sequences. Consensus primers were used to generate the same unlabelled PCR product; digoxigenin labelled type specific probes for HPV6, 11, 16, 18, 31, and 33 were used and hybrids visualised by colorimetric immunoenzymatic reaction. Thirty nine biopsy specimens and 31 cytological samples were tested by the PCR-ELISA and by standard PCR followed by dot-blot hybridisation.
\end{abstract}

Results-The PCR-ELISA proved to be more sensitive than standard PCR with dot-blot hybridisation typing. All samples positive for HPV-DNA in standard PCR with dot-blot hybridisation method were confirmed positive by the PCR-ELISA assay; however, seven samples were positive only by PCR-ELISA.

Conclusions-The PCR-ELISA assay, which can be performed in one day, is easily standardised and therefore seems to be a practical, sensitive, and reliable diagnostic tool for the detection and typing of HPV genomes in biopsy and in cytological specimens in the routine diagnostic laboratory.

(F Clin Pathol 1998;51:143-148)

Keywords: human papillomavirus; polymerase chain reaction; typing
Human papillomavirus (HPV) infections are related to several cutaneous and mucosal dysplasias, including both benign and malignant lesions. ${ }^{1-8}$ The HPVs are commonly referred to as high, intermediate or low oncogenic risk, depending on the frequency with which they are associated with malignancy. The high risk types include HPV16, 18, 45, and 56; HPV31, 33, and 35 are intermediate risk types; and HPV6, 11, 42, 43, and 44 are low risk.

As HPVs cannot be propagated in cell cultures, and only small amounts of viral antigens are present in body fluids, ${ }^{9}$ the diagnosis of HPV infection mainly relies on HPV nucleic acid detection. ${ }^{10}$ The most common methods used to detect and type HPV DNAs are: Southern blot, ${ }^{11}{ }^{12}$ dot-blot, ${ }^{13}$ in situ hybridisation (ISH), ${ }^{14}{ }^{15}$ and polymerase chain reaction (PCR).

Nucleic acid amplification techniques such as $\mathrm{PCR}^{16}$ are valid tools for the diagnosis of HPV related diseases. ${ }^{17}$ In fact PCR amplification allows rapid and specific detection of low abundance viruses and a single genome copy can be detected in clinical specimens. Many PCR protocols use either primers recognising specific HPV open reading frames (ORFs) ${ }^{18}$ or common highly conserved sequences among different HPV types. ${ }^{19}{ }^{20}$ Typing of HPV DNA generated by PCR with consensus primers can be performed by restriction fragment length polymorphism, ${ }^{21}$ by direct DNA sequence analysis, ${ }^{22}$ and by dot-blot hybridisation with type specific probes. ${ }^{23}$ Several hybrid capture immunoassays have recently been developed for the detection and typing of PCR products. ${ }^{24-29}$

In this study a hybridisation capture assay in microplates was compared to dot-blot hybridisation for the detection and typing of PCR amplified HPV DNAs in 39 paraffin wax embedded biopsies and 31 cytological specimens.

\section{Methods}

CLINICAL SPECIMENS

Ten micrometer sections were cut from 39 paraffin wax embedded biopsy samples. Tissue specimens were selected according to clinical, histological, and/or histochemical findings: 3 were classified as warts, 7 as genital condylomas, 1 as Bushke-Lowenstein tumour, 5 as cervical intraepithelial neoplasias (CIN I and CIN II), 3 as epithelial lesions of the penis, 6 as squamous cell carcinomas, 3 as cutaneous
Accepted for publication 11 November 1997 
Bowen's disease, 2 as bowenoid papulosis, 2 as verrucous carcinomas, 1 as laryngeal lesion, 1 as tongue condyloma, 3 as papular lesions in epidermodysplasia verruciformis, and 2 as gastric papillomas.

Thirty one cervical scrapes were selected according to clinical, colposcopic, cytological, and/or histochemical findings: 3 were classified as cervical condylomas, 18 as CIN I, 6 as CIN II, and 4 as CIN III.

All 70 clinical specimens and 4 reference clinical specimens negative for HPV DNAs were tested either by standard PCR ${ }^{19}$ with dotblot hybridisation ${ }^{23}$ or by the PCR-ELISA method.

SPECIFICITY AND SENSITIVITY CONTROLS

The cervical carcinoma cell line CaSki, which contains 500-600 HPV16 DNA copies per cell, and HeLa, which contains 20-50 HPV18 DNA copies per cell, were used as positive controls. To determine the sensitivity of standard PCR dot-blot hybridisation and the PCR-ELISA method, 10-fold dilutions up to $10^{-6}$ of $10^{3} \mathrm{HeLa}$ or CaSki cell lysates were tested.

Four paraffin wax embedded biopsy specimens, analysed by ISH (Kreatech, the Netherlands) with subgenomic type specific probes and proved positive for HPV6, 11, 31, and 33 respectively, were used as positive controls. The biopsies were dewaxed and digested as described below. Then end point dilutions of the lysates were performed and tested by standard PCR with dot-blot hybridisation. The highest dilution, which proved positive by standard PCR with dot-blot hybridisation, was introduced as a reference positive control for the PCR-ELISA method.

Human fibroblast cell line MRC-5 was used as a negative control. Ten microliters of $10^{3}$ MRC- 5 cell lysate were processed. In addition, reference specimens from four paraffin wax embedded cutaneous biopsies unrelated to HPV induced lesions and negative for HPV DNAs were analysed. The values obtained for the MRC- 5 negative control by PCR-ELISA were in the range of the values obtained for reference specimens negative for HPV DNAs $(\mathrm{p}<0.01)$.

DNA PREPARATION

Paraffin wax embedded sections from biopsy specimens were dewaxed twice in xylene, dehydrated in absolute ethanol, and protease digested by incubation at $55^{\circ} \mathrm{C}$ for two hours in $200 \mu \mathrm{l}$ of digestion buffer $(50 \mathrm{mM} \mathrm{KCl}$, $10 \mathrm{mM}$ Tris- $\mathrm{HCl} \mathrm{pH} 8.3,0.05 \%$ Tween 20 and $400 \mu \mathrm{g} / \mathrm{ml}$ of proteinase $\mathrm{K}$ ), followed by heat inactivation at $95^{\circ} \mathrm{C}$ for 10 minutes.

Cytological specimens from cervical scrapes were collected in phosphate buffered saline (PBS), centrifuged, and the pellets digested with buffer as described above.

Confluent monolayers from HeLa, CaSki, and MRC-5 cell lines were harvested by trypsinisation, washed with PBS, and spun down. The pellet was digested with buffer as described above.
PRIMERS AND PROBES

Consensus primer pair MY09 and MY11, ${ }^{19}$ able to detect more than 25 different HPV types within the L1 ORF, were used in PCR amplification.

Oligonucleotide probes MY12, MY13, MY14, WD74, WD128, and MY59 ${ }^{23}$ specific to the L1 PCR products of HPV6, 11, 16, 18, 31 , and 33 , respectively, were used in hybridisation reactions.

As amplification control, primers $\mathrm{GH} 20$ and PC $04,{ }^{30}$ recognising human $\beta$ globin gene sequence, were used in each PCR reaction and amplified products were detected by $\mathrm{PC} 03$ probe.

All the hybridisation probes used in the PCR-ELISA method were 5' labelled with biotin, while all hybridisation probes used in standard PCR with dot-blot hybridisation were 5' labelled with digoxigenin.

STANDARD PCR AND DOT-BLOT HYBRIDISATION Standard PCR was performed simultaneously for amplification of HPV sequences and human $\beta$ globin sequence. HPVs were amplified by consensus primers. ${ }^{19}$ Amplification products were visualised through $2 \%$ agarose gel with ethidium bromide staining and were then analysed by dot-blot hybridisation ${ }^{23}$ with digoxigenin labelled internal probes specifically for HPV types $6,11,16,18,31$, and 33 . Hybridised digoxigenin labelled probes were then visualised colorimetrically by immunoenzymatic reaction using antidigoxigenin Fab fragments labelled with alkaline phosphatase. ${ }^{31}$

PCR-ELISA METHOD

DNA amplification and labelling

DNA amplification and labelling was performed in $50 \mu \mathrm{l}$ PCR reaction volume containing $50 \mathrm{mM} \mathrm{KCl}, 10 \mathrm{mM}$ Tris- $\mathrm{HCl}$ $\mathrm{pH} 8.2,4 \mathrm{mM} \mathrm{MgCl}, 0.1 \mathrm{mM}$ dATP, $0.1 \mathrm{mM}$ dGTP, $0.1 \mathrm{mM}$ dCTP, $0.095 \mathrm{mM}$ dTTP, $0.005 \mathrm{mM}$ digoxigenin-11-dUTP (Boehringer Mannheim, Mannheim, Germany), $0.1 \mu \mathrm{M}$ each primer MY09, MY11, GH20, and PC04, 2.5 Units Taq DNA polymerase, and $10 \mu \mathrm{l}$ of each digested sample.

After an initial denaturation step at $95^{\circ} \mathrm{C}$ for five minutes, 40 cycles were performed of one minute at $95^{\circ} \mathrm{C}$, one minute at $55^{\circ} \mathrm{C}$, two minutes at $72^{\circ} \mathrm{C}$, followed by a final extension step of five minutes at $72^{\circ} \mathrm{C}$.

\section{Hybridisation and detection reaction}

Amplified products, labelled with digoxigenin during the amplification reaction, were separately hybridised with type specific biotinylated probes for HPV6, 11, 16, 18, 31, and 33, and with biotinylated probe for human $\beta$ globin gene sequence. A volume of $5 \mu 1$ of amplified product was added to $5 \mu \mathrm{l}$ of denaturing solution (100 mM NaOH, $0.1 \%$ Tween-20) and incubated at $25^{\circ} \mathrm{C}$ for 10 minutes. Then $190 \mu \mathrm{l}$ of hybridisation solution (300 mM $\mathrm{NaCl}, 100 \mathrm{mM}$ Tris- $\mathrm{HCl}$ pH 6.5, $10 \mathrm{mM}$ EDTA, $0.1 \%$ Tween-20), containing $2 \mathrm{pmol} /$ $\mathrm{ml}$ of a type specific probe were added and hybridisation was performed at $55^{\circ} \mathrm{C}$ for 10 minutes. Each reaction volume was transferred 

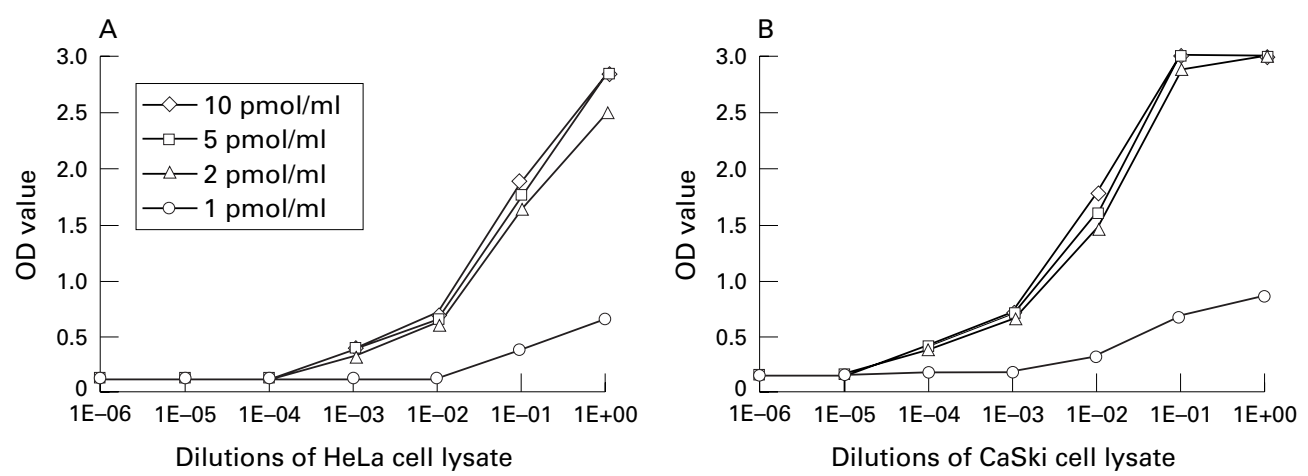

Figure 1 PCR products obtained from 10-fold dilutions of $10^{3} \mathrm{HeLa}(A)$ or CaSki $(B)$ cell lysates hybridised with four different concentrations $(1,2,5$, and $10 \mathrm{pmol} / \mathrm{ml}$ ) of type specific probe (WD74 and MY14). The hybrids were captured in microtitre plate wells.

to a streptavidin coated microtitre plate well (Boehringer Mannheim) and incubated at $25^{\circ} \mathrm{C}$ for 50 minutes. Plates were then washed five times with TBST $(150 \mathrm{mM} \mathrm{NaCl}$, $100 \mathrm{mM}$ Tris- $\mathrm{HCl} \mathrm{pH} 7.5,0.1 \%$ Tween-20). A volume of $200 \mu \mathrm{l}$ of antidigoxigenin POD conjugated solution $(10 \mathrm{mU} / \mathrm{ml}$ in TBST) (Boehringer Mannheim) was added and incubated at $25^{\circ} \mathrm{C}$ for 30 minutes. After washing five times in TBST, $200 \mu \mathrm{l}$ of ABTS substrate solution was added to each well, and developed for 30 minutes at room temperature. The colorimetric reaction was measured by spectrophotometry at the optical density (OD) of $405 \mathrm{~nm}$.

As the values of the MRC- 5 negative control were in the range of values obtained for reference negative specimens, the cut off of the reaction was determined as twice the mean value of a negative MRC- 5 control tested in triplicate. This corresponds to the OD value obtained from HeLa and CaSki cell lysates containing 20-50 copies of HPV18 DNA and 50-60 copies of HPV16 DNA, respectively. Test samples with values in the range of $\pm 20 \%$ of the cut off value were retested.

Results were expressed as net absorbence after the absorbence of the buffer blank was subtracted and index value was calculated as OD of the sample/cut off; index value $>1$ was considered positive.

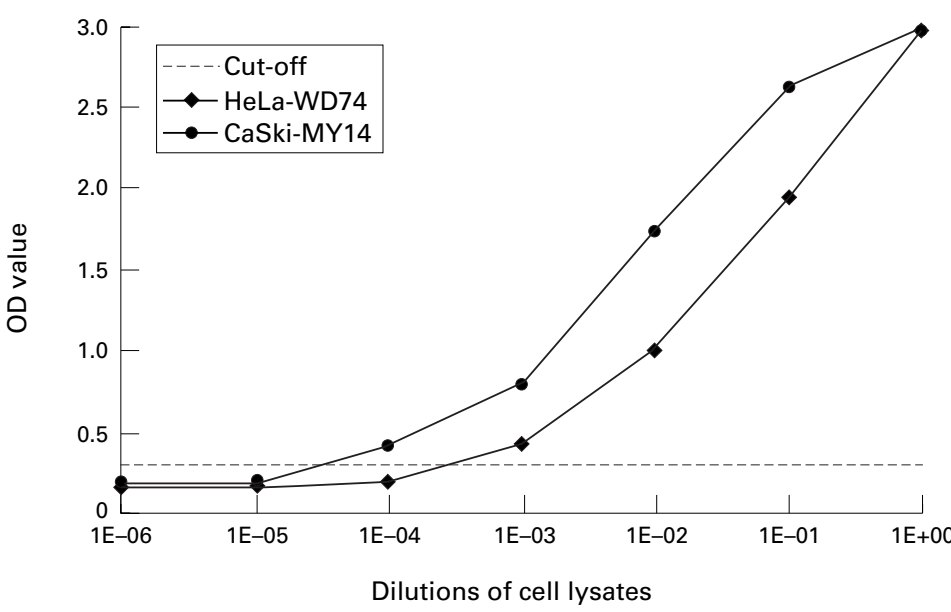

Figure 2 PCR products obtained from 10-fold dilutions of $10^{3} \mathrm{HeLa}$ or CaSki cell lysates were hybridised with WD74 and MY14 probes, respectively. The hybrids were captured in microtitre plate wells.

\section{Results}

To determine the optimum amount of type specific probes to use in the hybridisation reaction, four different concentrations $(1,2,5$, and $10 \mathrm{pmol} / \mathrm{ml}$ ) of WD74 or MY14 probes specific for HPV18 and HPV16, respectively, were hybridised with PCR amplified products obtained from 10-fold dilutions of $10^{3} \mathrm{HeLa}$ (fig 1A) or CaSki (fig 1B) cell lysates, respectively.

The hybridisation signal reached the maximum value when a concentration of $2 \mathrm{pmol} / \mathrm{ml}$ of each probe was used at the different concentrations of HeLa or CaSki cells tested. The signal remained constant even at higher probe concentrations. Therefore a probe concentration of $2 \mathrm{pmol} / \mathrm{ml}$ was used in all the experiments.

To determine the sensitivity of the reaction, a lysate from $10^{3} \mathrm{HeLa}$ or CaSki cells was diluted up to $10^{-6}$ and amplified by PCR. Hybridisation and capture assay of amplified products proved positive up to $10^{-4}$ for CaSki (about 50-60 genome copies) and up to $10^{-3}$ for $\mathrm{HeLa}$ cells (about 20-50 genome copies) (fig 2). When the same dilutions of HeLa and CaSki cell lysates were amplified by standard PCR and detected with digoxigenin labelled specific probes, the assay proved positive up to $10^{-3}$ for CaSki cells and up to $10^{-2}$ for HeLa cells.

The specificity of the PCR-ELISA was assessed on MRC-5 cell lysate. No amplified products were detected when PCR treated MRC-5 cell lysate was hybridised with type specific probes for HPV6, 11, 16, 18, 31, and 33 , and captured in a microtitre plate well. No cross reactions were observed when amplified products from HeLa were hybridised with MY12, MY13, MY14, WD128, MY59 specific for HPV6, 11, 16, 31, and 33, respectively, and amplified products from CaSki were hybridised with MY12, MY13, WD74, WD128, MY59 specific for HPV6, 11, 18, 31, and 33, respectively (data not shown).

To test the reproducibility of the PCR assay, dilutions from $\mathrm{HeLa}$ and CaSki cell lysates were amplified in three independent PCR assays and amplified products detected by the ELISA method in the same plate. The difference observed in OD values between replicate PCR samples was assessed at about $4 \%$. 
Table 1 HPV detection and typing in paraffin wax embedded biopsy specimens

\begin{tabular}{|c|c|c|c|c|}
\hline Sample & Diagnosis & PCR dot-blot & PCR-ELISA & Index value \\
\hline 1 & Vulvar condyloma & HPV6 & HPV6 & 1.04 \\
\hline 2 & Vulvar condyloma & HPV6 & HPV6 & 1.23 \\
\hline 3 & Vulvar condyloma & HPV6 & HPV6 & 7.04 \\
\hline 4 & Bushke-Lowenstein tumour & HPV6 & HPV6 & 4.33 \\
\hline \multirow[t]{2}{*}{5} & Wart & HPV6 & HPV6 & 1.46 \\
\hline & & HPV11 & HPV11 & 2.84 \\
\hline 6 & Vulvar condyloma & HPV11 & HPV11 & 1.29 \\
\hline 7 & Vulvar condyloma & HPV11 & HPV11 & 1.14 \\
\hline 8 & Periungueal squamous cell carcinoma & HPV16 & HPV16 & 4.74 \\
\hline 9 & Cutaneous Bowen's disease & HPV16 & HPV16 & 4.20 \\
\hline 10 & Cutaneous Bowen's disease & HPV16 & HPV16 & 3.66 \\
\hline 11 & Cutaneous Bowen's disease & HPV16 & HPV16 & 5.36 \\
\hline 12 & Vulvar condyloma & HPV16 & HPV16 & 8.38 \\
\hline 13 & Gastric papilloma & HPV16 & HPV16 & 9.87 \\
\hline 14 & Gastric papilloma & HPV16 & HPV16 & 3.88 \\
\hline 15 & CIN II & HPV16 & HPV16 & 3.46 \\
\hline 16 & CIN II & HPV33 & HPV33 & 5.68 \\
\hline 17 & Vulvar condyloma & Negative & HPV6 & 1.14 \\
\hline 18 & Bowenoid papulosis & Negative & HPV16 & 2.00 \\
\hline 19 & Subungueal squamous cell carcinoma & Negative & HPV16 & 1.86 \\
\hline 20 & Bowenoid papulosis & Negative & HPV18 & 1.30 \\
\hline 21 & Verrucous carcinoma & Negative & HPV33 & 1.44 \\
\hline 22 & Laryngeal lesion & Negative & Negative & \\
\hline 23 & Periungueal squamous cell carcinoma & Negative & Negative & \\
\hline 24 & Wart & Negative & Negative & \\
\hline 25 & Periungueal squamous cell carcinoma & Negative & Negative & \\
\hline 26 & Subungueal squamous cell carcinoma & Negative & Negative & \\
\hline 27 & Subungueal squamous cell carcinoma & Negative & Negative & \\
\hline 28 & Wart & Negative & Negative & \\
\hline 29 & $\begin{array}{l}\text { Papular lesion in epidermodysplasia } \\
\text { verruciformis }\end{array}$ & Negative & Negative & \\
\hline 30 & $\begin{array}{l}\text { Papular lesion in epidermodysplasia } \\
\text { verruciformis }\end{array}$ & Negative & Negative & \\
\hline 31 & $\begin{array}{l}\text { Papular lesion in epidermodysplasia } \\
\text { verruciformis }\end{array}$ & Negative & Negative & \\
\hline 32 & Tongue condyloma & Negative & Negative & \\
\hline 33 & Verrucous carcinoma & Negative & Negative & \\
\hline 34 & CIN I & Negative & Negative & \\
\hline 35 & CIN II & Negative & Negative & \\
\hline 36 & CIN II & Negative & Negative & \\
\hline 37 & Epithelial lesion of penis & Negative & Negative & \\
\hline 38 & Epithelial lesion of penis & Negative & Negative & \\
\hline 39 & Epithelial lesion of penis & Negative & Negative & \\
\hline
\end{tabular}

HPV genotyping was performed with probes specific for HPV6, 11, 16, 18, 31, and 33. Index value was calculated as optical density of the sample/cut off in each microtitre plate.

Table 2 HPV detection and typing in cytological specimens

\begin{tabular}{|c|c|c|c|c|}
\hline Sample & Diagnosis & PCR dot blot & PCR-ELISA & Index value \\
\hline 1 & Cervical condyloma & HPV6 & HPV6 & 8.56 \\
\hline 2 & Cervical condyloma & HPV16 & HPV 16 & 4.24 \\
\hline 3 & Cervical condyloma & HPV16 & HPV 16 & 1.90 \\
\hline 4 & CIN I & HPV16 & HPV16 & 4.53 \\
\hline 5 & CIN I & HPV16 & HPV16 & 3.76 \\
\hline 6 & CIN I & HPV16 & HPV16 & 2.43 \\
\hline 7 & CIN II & HPV16 & HPV16 & 1.76 \\
\hline 8 & CIN III & HPV16 & HPV16 & 2.16 \\
\hline 9 & CIN I & HPV31 & HPV31 & 8.32 \\
\hline 10 & CIN I & HPV31 & HPV31 & 3.54 \\
\hline 11 & CIN I & HPV31 & HPV31 & 2.33 \\
\hline 12 & CIN II & HPV31 & HPV31 & 4.56 \\
\hline 13 & CIN II & HPV31 & HPV31 & 3.12 \\
\hline 14 & CIN I & HPV33 & HPV33 & 2.47 \\
\hline 15 & CIN II & HPV33 & HPV33 & 1.68 \\
\hline 16 & CIN III & HPV33 & HPV33 & 7.44 \\
\hline 17 & CIN III & HPV33 & HPV33 & 3.01 \\
\hline 18 & CIN III & HPV33 & HPV33 & 3.18 \\
\hline 19 & CIN II & Negative & HPV6 & 1.24 \\
\hline 20 & CIN I & Negative & HPV31 & 1.19 \\
\hline 21 & CIN I & Negative & Negative & \\
\hline 22 & CIN I & Negative & Negative & \\
\hline 23 & CIN I & Negative & Negative & \\
\hline 24 & CIN I & Negative & Negative & \\
\hline 25 & CIN I & Negative & Negative & \\
\hline 26 & CIN I & Negative & Negative & \\
\hline 27 & CIN I & Negative & Negative & \\
\hline 28 & CIN I & Negative & Negative & \\
\hline 29 & CIN I & Negative & Negative & \\
\hline 30 & CIN I & Negative & Negative & \\
\hline 31 & CIN II & Negative & Negative & \\
\hline
\end{tabular}

HPV genotyping was performed with probes specific for HPV6, 11, 16, 18, 31, and 33. Index value was calculated as optical density of the sample/cut off in each microtitre plate.
To measure the reproducibility of the ELISA method, dilutions from HeLa and CaSki cell lysates were amplified in PCR and hybridised with specific probes. The hybrids were captured in three different streptavidin coated wells and the difference observed in OD values between replicate samples was assessed at about $2 \%$.

As positive controls for HPV DNAs types 16 and $18, \mathrm{CaSki}$ and HeLa cell lysates were used in the experiments at dilutions of $10^{-3}$ and $10^{-2}$, respectively. In addition, reference clinical specimens positive for HPV DNAs types 6,11 , 31 , and 33 were used at $10^{-3}, 10^{-3}, 10^{-4}$, and $10^{-4}$, respectively.

Thirty nine paraffin wax embedded tissue specimens and 31 cytological specimens were tested by the PCR-ELISA method. All the specimens had previously been analysed by standard PCR and typed by dot-blot hybridisation with specific probes. With the standard technique, 23 samples had proved negative for HPV6, 11, 16, 18, 31, and 33, and 16 had proved positive for HPV DNAs (table 1). Of the cytological samples tested, 13 were negative and 18 positive (table 2 ).

With the PCR-ELISA method 18 of the 39 biopsy specimens analysed proved negative for HPV DNAs, and 21 proved positive (table 1). Eleven of the 31 cytological specimens analysed proved negative for HPV DNAs and 20 proved positive (table 2). All biopsy and cytological specimens were positive for human $\beta$ globin gene sequence.

Reference positive controls proved positive in each experiment with both methods tested. Four reference negative biopsies proved negative both by standard PCR with dot-blot hybridisation and by the PCR-ELISA method. No cross contaminations from microtome cut were detected-paraffin slices treated as clinical specimens proved negative for HPV6, 11, $16,18,31$, and $33 \mathrm{DNA}$, and there was no contamination during PCR amplification tested by the presence of MRC- 5 negative controls and blank samples (PCR reagents without a DNA template) run in each assay.

To test the reproducibility of the results, three positive and two negative clinical specimens by the PCR-ELISA were retested in three independent assays and the results were confirmed.

All samples positive for HPV DNA by standard PCR with dot-blot hybridisation method were confirmed positive in the PCRELISA assay; however, seven samples were positive only by PCR-ELISA: 2 were identified as HPV6, 2 as HPV16, 1 as HPV18, 1 as HPV31, and 1 as HPV33.

\section{Discussion}

Several diagnostic techniques have been used for the diagnosis of HPV infections. Currently PCR assay offers the greatest sensitivity and the use of consensus primers allows the amplification of a broad spectrum of HPV types. $^{192032}$ Many technical strategies have been developed to type and quantify HPV DNA sequences amplified by consensus primers. ${ }^{27}$ 33-39 
We evaluated a semiquantitative method to detect and type HPV amplified sequences, this method, able to give an objective evaluation of the results, was compared with dot-blot hybridisation.

In the PCR-ELISA, the well conserved L1 region of the HPV genome was amplified by consensus primers and directly labelled with digoxigenin during amplification reaction. The direct incorporation of a labelled nucleotide during amplification reaction increases the sensitivity of the assay with respect to extension labelling primers, giving a more efficient labelling. ${ }^{24}$ In fact, one digoxigenin-dUTP is incorporated approximately every 20 dTTPs into an amplified region of 450 base pairs.

The specificity and typing of amplified products was assured by biotinylated oligoprobes specific for HPV16, 18, 31, 33, 6, and 11, considered at high, intermediate, and low risk for their oncogenic potential. This method, however, can be adapted to the detection of all HPV genotypes and represents a valid tool to study the pathogenicity of the different genotypes.

The PCR-ELISA method can be adapted to screen HPV DNA positive clinical samples using MY18 and MY57 generic probes, ${ }^{23}$ but in our experience the assay proved less sensitive with degenerated probes (data not shown). Furthermore, a second hybridisation reaction to identify type specific HPV DNAs is necessary. However, if the diagnosis of the laboratory can be limited to detect HPV DNAs and discriminate the oncogenic potential of HPVs, the use of two cocktails of oligonucleotide probes can be used to recognise high and low risk HPVs. ${ }^{27}{ }^{39}$ This method is less time consuming and technically demanding but it allows only a limited reduction of costs as the cost is mainly attributable to the probes.

Digoxigenin labelled PCR products, hybridised with specific biotinylated probes, were captured into streptavidin coated microtitre wells by a biotin-streptavidin binding and detected by an immunoenzymatic reaction. ${ }^{29}$ The colorimetric reaction was automatically detected by spectrophotometry and semiquantitative determination of HPV type specific DNA was achieved by comparison with positive reference samples. Of the 39 biopsy specimens and the 31 cytological scrapes tested, 18 and 11 , respectively proved negative by both the PCR-ELISA and standard method. These results could indicate that the clinical diagnosis does not always correlate with the laboratory investigation. Otherwise HPV genotypes other than those investigated could be present.

When the 70 clinical specimens were tested both by the PCR-ELISA and the standard PCR with dot-blot hybridisation, seven samples were positive by the PCR-ELISA only. The discrepancy of the results could be interpreted as a higher sensitivity for the PCRELISA than standard PCR with dot-blot hybridisation, probably because of the higher efficiency of the labelling method used.

With the PCR-ELISA, evaluation of results is objective and semiquantitative data can be obtained, while dot-blot hybridisation requires a subjective interpretation and, at low viral concentration, the interpretation of the results could be doubtful.

The possibility of obtaining semiquantitative data by the PCR-ELISA is particularly useful as the viral load seems to predict the clinical course of the infection and is implicated in maternal-infant transmission. ${ }^{35} 40$

This assay can be performed in one day, is easily standardised and therefore seems to be a practical, sensitive, and reliable diagnostic tool for the detection and typing of HPV genomes in biopsy and cytological specimens in the routine diagnostic laboratory.

The skilful technical help of Ms Marinella Plazzi and Ms Consuelo Corsini is gratefully acknowledged. This work was partially supported by a Ministry of University and Scientific Research grant and by the University of Bologna Funds for selected research topics and by CNR Target Project Biotechnology

1 Abramson AL, Brandsma JL, Steinberg BM, et al. Verrucous carcinoma on the larynx. Possible human papillomavirus etiology. Arch Otolaryngol 1985;111:709-15.

2 de Villiers EM. Heterogeneity of the human papillomavirus group. I Virol 1989;63:4898-903.

3 Howley PM. The role of papillomavirus in human cancer. In: De Vita VC Jr, Hellman S, Rosenberg SA, eds. Important advances in oncology. Philadelphia: Lippincott, 1987:55-73.

4 Löning T, Ikenberg H, Becker J, et al. Analysis of oral papillomas, leukoplakias, and invasive carcinomas for human papillomavirus type related DNA. F Invest Dermatol 1985;84:417-20.

5 Schwartz RA, Janninger CK. Bowenoid papulosis. f Am Acad Dermatol 1991;24(2 pt 1):261-4.

6 Tosti A, La Placa M, Fanti P, et al. Human papillomavirus type 16 associated periungueal squamous cell carcinoma in a patient with acquired immunodeficiency syndrome. Acta Derm Venereol 1994;74:478-9.

7 Tyan YS, Liu ST, Ong WR, et al. Detection of Epstein Barr virus and human papillomavirus in head and neck tumors. f Clin Microbiol 1993;31:53-6.

8 zur Hausen $\mathrm{H}$. Human papillomavirus in the pathogenesis of anogenital cancer. Virology 1991;184:9-13.

9 Bennet Jenson A, Kurman RJ, Lancaster WD. Detection of human papillomavirus common antigens in lesions of skin and mucosa. Clin Dermatol 1985;3:56-63.

10 Schneider A. Methods for detection of human papillomaviruses. In: Syrjaven K, Gissmann Koss L, eds. Papillomaviruses and human disease. Heidelberg: Springer-Verlag, 1987:19-39.

11 Brandsma J, Burk RD, Lancaster WD, et al. Inter-laboratory variation as an explanation for varying prevalence estimates variation as an explanation for varying prevalence estimates of huma-2.

12 Roman A, Fife KH. Human papillomaviruses: are we ready to type? Clin Microbiol Rev 1989;2:166-90.

13 Cornelissen MTE, van der Velden KJ, Walboomers JM, et al. Evaluation of different DNA-DNA hybridization tecniques in detection of HPV16 DNA in cervical smears and biopsies. F Med Virol 1988;25:105-14.

14 Beckmann AM, Myerson D, Daling JR, et al. Detection and localization of human papillomavirus DNA in human genital condylomas by in situ hybridization with biotinylated probes. $\mathcal{F}$ Med Virol 1985;16:265-78.

15 Park RS, Kurman RJ, Keissis TD, et al. Comparison of peroxidase labeled DNA probes with radioactive RNA probes for detection of human papillomaviruses by in situ hybridization in paraffin sections. Mod Pathol 1991;4:81-5.

16 Mullis KB, Faloona FA. Specific synthesis of DNA in vitro via a polymerase-catalyzed chain reaction. Methods Enzyvia a polymerase-cat
mol $1987 ; 35: 335-50$.

17 Hildesheim A, Schiffman MH, Gravitt PE, et al. Persistence of type-specific human papillomavirus infection among cytologically normal women. F Infect Dis 1994;169:235-40.

18 Cornelissen MTE, van den Tweel JG, Struyck APHB, et al. Localization of human papillomavirus type 16 DNA using the polymerase chain reaction in the cervix uteri of women with cervical intraepithelial neoplasia. $\mathcal{F}$ Gen Virol 1989;70: 2555-62.

19 Manos MM, Ting Y, Wright DK, et al. Use of polymerase chain reaction amplification for the detection of genital human papillomaviruses. Cancer Cells 1989;7:209-14.

20 Snijders PJF, van den Brule AJC, Schrijnemakers HFJ, et al. The use of general primers in the polymerase chain reaction permits the detection of a broad spectrum of human papillomavirus genotypes. f Gen Virol 1990;71: human

21 Contorni M, Leoncini P. Typing of human papillomavirus DNAs by restriction endonuclease mapping of the PCR products. F Virol Methods 1993;41:29-36.

22 Smits HL, Tieben LM, Tjong-A-Hung SP, et al. Detection and typing of human papillomavirus present in fixed and 
stained archival cervical smears by a consensus polymerase chain reaction and direct sequence analysis allow the identification of a broad spectrum of human papillomavirus types. F Gen Virol 1992;73:3263-8.

23 Resnick RM, Cornelissen MTE, Wright DK, et al. Detection and typing of human papillomavirus in archival cervical cancer specimens by DNA amplification with consensus primers. F Nat Cancer Inst 1990;82:1477-84.

24 Adams V, Moll C, Schmid M, et al. Detection and typing of human papillomavirus in biopsy and cytological specimen by polymerase chain reaction and restriction enzyme analysis. A method suitable for semiautomation. $7 \mathrm{Med}$ Virol 1996;48:161-70.

25 Cox JT, Lorincz AT, Schiffman MH, et al. Human papillomavirus testing by hybrid capture appears to be useful in triaging women with a cytologic diagnosis of atypical squamous cells of undetermined significance. Am $\mathcal{F}$ Obstet Gynecol 1995;172:946-54.

26 Gibellini D, Zerbini M, Musiani M, et al. Microplate capture hybridization of amplified parvovirus B19 DNA capture hybridization of amplified parvovirus B19 DNA fragment

27 Jacobs MV, de Roda Husman AM, van den Brule AJC, et al. Group-specific differentiation between high- and low-risk human papillomavirus genotypes by general primermediated PCR and two cocktails of oligonucleotide probes. f Clin Microbiol 1995;33:901-5.

28 Poljak M, Seme K. Rapid detection and typing of human papillomaviruses by consensus polymerase chain reaction and enzyme-liked immunosorbent assay. 7 Virol Methods 1996;56:231-8

29 Zerbini M, Gibellini D, Musiani M, et al. Automated detection of digoxigenin-labelled B19 parvovirus amplicons by a

30 Saiki RK, Scharf S, Faloona FA, et al. Enzymatic amplification of a $\beta$-globin genomic sequence and restriction site tion of a $\beta$-globin genomic sequence and restriction site 1985;230:1350-4.

31 Zerbini M, Musiani M, Venturoli S, et al. Rapid screening for B19 parvovirus DNA in clinical specimens with a
digoxigenin-labeled DNA hybridization probe. $f$ Clin digoxigenin-labeled DNA
32 Gregoire L, Arella M, Campione-Piccardo J, et al. Amplification of human papillomavirus DNA sequences by using conserved primers. F Clin Microbiol 1989;27:2660-5.

33 Bavin PJ, Giles JA, Deery A, et al. Use of semi-quantitative PCR for human papillomavirus DNA type 16 to identify women with high grade cervical disease in a population presenting with a mildly dyskaryotic smear report. $\mathrm{Br} \mathcal{F}$ Cancer 1993;67:602-5.

34 Lungu O, Wei Sun X, Wright TC, et al. A polymerase chain reaction-enzyme-linked immunosorbent assay method for detecting human papillomavirus in cervical carcinomas and high-grade cervical cancer precursors. Obstet Gynecol 1995;85:337-42.

35 Morrison EAB, Burk RD. PCR detection of human papillomavirus: quantitation may improve clinical utility. In: Becker Y, Darai G, eds. PCR protocols for diagnosis of In: Becker Y, Darai G, eds. PCR protocols for diagnosis of
human and animal virus diseases. Heidelberg: SpringerVerlag, 1995:279-86.

36 Venuti A, Badaracco G, Marcante ML. Detection and typing of human papillomavirus by single hybridization. $\mathcal{F}$ Virol Methods 1995;51:115-24.

37 Ylitalo N, Bergström T, Gyllensten U. Detection of genital human papillomavirus by single-tube nested PCR and type-specific oligonucleotide hybridization. F Clin Microbiol 1995;33:1822-8.

38 Cavuslu S, Starkey WG, Kaye JN, et al. Detection of human papillomavirus type-16 DNA utilising microtitre-plate based amplification reactions and a solid-phase enzymeimmunoassay detection system. I Virol Methods 1996;58: immun 69 .

39 Jacobs MV, Snijders PJF, Adriaan JC, et al. A general primer GP5+/GP6+-mediated PCR-enzyme immunoassay method for rapid detection of 14 high-risk and 6 low-risk human papillomavirus genotypes in cervical scrapings. $\mathcal{f}$ Clin Microbiol 1997;35:791-5.

40 Morrison EAB, Goldberg GL, Kadish AS, et al. Polymerase chain reaction detection of human papillomavirus: quantichain reaction detection of human papilomavirus: quanti-
tation may improve clinical utility. $f$ Clin Microbiol 1992;30:2539-43. 